\title{
ANALISIS TRANSPOR SEDIMEN SERTA PENGARUH AKTIVITAS PENAMBANGAN PADA SUNGAI SOMBE, KOTA PALU, SULAWESI TENGAH
}

\author{
Muhammad Iqbal Pratama ${ }^{1}$, Djoko Legono², Adam Pamudji Rahardjo \\ ${ }^{1)}$ Peneliti Keairan, J1.Setia Budi Lrg IV B No.90, Palu, Sulawesi Tengah, Indonesia; \\ Pratamaiqbal4554@gmail.com \\ ${ }^{2)}$ Departemen Teknik Sipil dan Lingkungan, Universitas Gadjah Mada, Yogyakarta, Indonesia
}

\begin{abstract}
ABSTRAK : Permasalahan sedimentasi yang terjadi di Sungai Sombe merupakan suatu fenomena terbawanya butiran atau partikel sedimen yang berasal dari longsoran tebing sungai. Hal tersebut diperparah ketika terjadi hujan dengan intensitas sedang hingga tinggi menyebabkan terbawanya material sedimen bersama banjir. Selain itu, adanya aktivitas penambangan pasir di Sungai Sombe juga dapat mempengaruhi terjadinya perubahan pada dasar sungai. Tujuan dari penelitian ini adalah untuk mengidentifikasi dan memperkirakan besaran angkutan sedimen dan pengaruh dari adanya aktifikasi penambangan terhadap perubahan dasar sungai pada Sungai Sombe. Pada penelitian ini dilakukan pengukuran langsung di Sungai Sombe untuk memperoleh sampel sedimen dan data morfologi sungai serta pengamatan terhadap aktivitas penambangan yang ada di Sungai Sombe, kemudian data - data yang telah dikumpulkan akan di analisis menggunakan metode Rottner dan Van Rijn. Hasil analisis diperoleh nilai rata - rata debit sedimen di Sungai Sombe dengan kala ulang 1 Tahunan, 2 Tahunan, 5 Tahunan dan 10 Tahunan, yaitu metode Rottner sebesar 2,1 x $10^{7}-3,8 \times 10^{7}$ Ton/tahun; dan metode Van Rijn sebesar 4,0 x10 $-6,9 \times 10^{7}$ Ton/tahun.
\end{abstract}

Kata Kunci : Angkutan sedimen, Sungai Sombe, Rottner, Van Rijn

\begin{abstract}
Sedimentation problems occuring in Sombe River is a phenomenon of sediment grainsor particles entrained from the riverbank avalanche. The problem is exacerbated when there is moderate to high intensity rainfall, causing sediment material transported by a flood. Moreover, sand mining activities also affect the changes in the riverbed. The research aims to identify and estimate the quantity of sediment transport and the effect of the mining activities on the riverbed changes in Sombe River. In this research, direct measurement in Sombe river and observation of the mining activities in Sombe River are conducted to collect sediment samples and river morphology data. Thenceforth, the collected data will be analyzed using Rottner and Van Rijn method. According to the result of the calculation, the average of sediment discharge in Sombe River with a return period of 1 year, 2 years, 5 years and 10 years are Rottner method is $2.1 \times 10^{7}-3.8 \times 10^{7}$ Tons/year; Van Rijn method is 4.0 $\times 10^{7}-6.9 \times 10^{7}$ Tons/years.
\end{abstract}

Keyword : Sediment transport, Sombe River, Rottner, Van Rijn. 
Sungai Sombe memiliki potensi yang sangat besar untuk berbagai keperluan baik untuk penduduk yang berada di sepanjang Sungai Sombe, maupun masyarakat Kota Palu. Selain dimanfaatkan untuk keperluan irigasi, dan air baku, juga digunakan untuk keperluan rekreasi yaitu dengan menyadap air Sungai Sombe bagi penyediaan air baku di tempat pemandian Porame. Material di sungai seperti pasir dan batu juga dimanfaatkan warga untuk pembangunan infrastruktur. Tetapi, dengan potensi yang ada tersebut Sungai Sombe memliki permasalahan yaitu sedimentasi. Hal ini diperparah ketika musim penghujan tiba, dimana hujan yang terjadi dengan intensitas sedang hingga tinggi seringkali menyebabkan banjir dan mengakibatkan banyaknya material sedimen dari hulu terbawa hingga ke hilir. Hal tersebut dapat mengancam pemukiman penduduk, lahan perkebunan dan pertanian serta infrastruktur yang ada. Selain itu, adanya aktivitas penambangan pasir di Sungai Sombe juga mempengaruhi terjadinya perubahan pada dasar sungai. Oleh karena itu, maka perlu adanya suatu studi yang mengkaji mengenai proses dan besaran angkutan yang terjadi serta pengaruh aktifitas penambangan terhadap perubahan dasar sungai pada Sungai Sombe.

\section{Angkutan Sedimen}

Menurut Mulyanto (2007) ada tiga macam angkutan sedimen yang terjadi di dalam alur sungai, antara lain:

a. Wash load atau muatan bilas adalah angkutan partike halus yang berupa lempung (silk) dan debu (dust) yang ikut tebawa masuk kedalam sungai dan melayang sampai mencapat laut atau genangan air lainnya.

b. Suspended load atau muatan sedimen melayang yang terdiri dari pasir halus dan bergerak secara melayang dalam aliran.

c. Bed load atau muatan sedimen dasar adalah butiran material dengan ukuran yang besar bergerak di dasar sungai dengan cara bergeser, menggelinding ataupun meloncat.

Sungai disebut dalam keadaan seimbang jika kapasitas sedimen yang masuk $\left(Q_{\text {in }}\right)$ pada suatu penampang memanjang sungai sama dengan kapasitas sedimen yang keluar (Q $Q_{\text {out }}$ ) dalam satuan waktu tertentu (Ismail Saud, 2008). Proses pengendapan di sungai dapat terjadi apabila jumlah sedimen yang masuk melebihi kapasitas sedimen seimbang dalam satuan waktu tertentu sedangkan proses erosi di sungai dapat terjadi apabila jumlah sedimen yang masuk kurang dari kapasitas sedimen seimbang dalam satuan waktu tertentu.

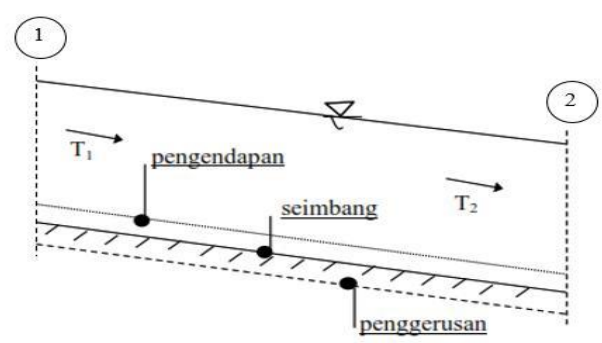

Gambar 1. Skema Angkutan Sedimen Melalui dua tampang sungai

Angkutan sedimen dapat menyebabkan terjadinya perubahan pada dasar sungai. pada Gambar 1. diperlihatkan bahwa angkutan sedimen pada suatu ruas sungai, akan mengalami penggerusan (erosi) atau pengendapan (deposisi), tergantung dari besar kecilnya angkutan sedimen yang terjadi sebagaimana yang ditampilkan pada Tabel 1.

Tabel 1. Klasifikasi Kondisi Dasar Sungai

\begin{tabular}{|c|c|c|}
\hline \multirow{2}{*}{$\begin{array}{c}\text { Angkutan } \\
\text { Sedimen (T) }\end{array}$} & \multicolumn{2}{|c|}{ Perubahan Dasar Sungai } \\
\cline { 2 - 3 } & Sedimen & Dasar Sungai \\
\hline $\mathrm{T}_{1}=\mathrm{T}_{2}$ & Seimbang & Stabil \\
\hline $\mathrm{T}_{1}<\mathrm{T}_{2}$ & Erosi & Degradasi \\
\hline $\mathrm{T}_{1}>\mathrm{T}_{2}$ & Sedimentasi & Agradasi \\
\hline
\end{tabular}

\section{Aktivitas Penambangan Pasir}

Aktivitas penambangan yang dilakukan di beberapa titik di Sungai Sombe semakin meningkat dan tidak terkendali, hal dapat mempengaruhi keseimbangan atau stabilitas sungai yang dapat menimbulkan terjadinya erosi atau degradasi pada dasar sungai. 


\section{Analisis Hidrologi}

Analisis hidrologi adalah kumpulan keterangan atau fakta mengenai fenomena hidrologi (hydrological phenomenon) seperti besarnya : curah hujan, temperatur, penguapan, lama penyinaran matahari, kecepatan angin, debit sungai, tinggi muka air sungai, kecepatan aliran, dan konsentrasi sedimen sungai yang selalu berubah menurut waktu (Yuliana,2008)

\section{Analisis Frekuensi}

Analisis frekuensi merupakan prakiraan (forecasting) dalam arti probabilitas untuk terjadinya suatu peristiwa hidrologi dalam bentuk hujan rancangan yang berfungsi sebagai dasar perhitungan perencanaan hidrologi untuk antisipasi setiap kemungkinan yang akan terjadi di masa akan datang. Pada analisis ini dilakukan pemilihan distribusi yang cocok untuk digunakan antara lain distribusi Normal, Log Normal, Gumbel dan Log Pearson tipe III.

\section{Uji kecocokan distribusi}

Uji sebaran dilakukan dengan uji kecocokan distribusi yang dimaksudkan untuk menentukan apakah persamaan distribusi peluang yang telah dipilih dapat menggambarkan atau mewakili dari sebaran statistik sampel data yang dianalisis tersebut (Soemarto, 1999). Untuk dapat menguji apakah jenis distribusi yang dipilih sesuai dengan data yang ada, maka dapat digunakan uji Chi-Kuadrat dan SmirnovKolmogorov (Sri Harto, 2009).

\section{Pola Distribusi Hujan}

\section{a. Intensitas Curah Hujan}

Lokasi penelitian yang berada di Sungai Sombe, dalam hal ini di Kota Palu khususnya belum memiliki pola distribusi hujan jam - jaman, sehingga digunakan pola distribusi dari daerah lain yang dapat mewakili atau mendekati karakteristik pola hujan yang ada di Kota Palu. Sehingga digunakan pola distribusi hujan di Sulawesi Utara yang berkisar antara $6-10$ jam, dalam penelitian ini diasumsikan pola distribusi hujan selama 6 jam.

\section{b. Alternating Block Method (ABM)}

Setelah diperoleh intensitas curah hujan maka dilakukan pengalihragaman curah hujan rancangan kedalam hujan jam jaman (Hyetograph) menggunakan model distribusi hujan yaitu metode Alternating Block Method (ABM).

\section{c. Hujan Efektif}

Hujan efektif merupakan bagian dari hujan yang tidak masuk kedalam tampungan dan tidak tertahan diatas permukaan tanah atau dapat disebut sebagai bagian hujan yang menimbulkan terjadinya limpasan langsung. Dalam menghitung hujan efektif pada penlitian ini digunakan persamaan indeks infiltrasi $\left(\Phi_{\text {Indeks }}\right)$, tetapi dikarenakan tidak tersedianya data debit aliran di sungai sombe, maka digunakan Metode SCS-CN (Soil Conservation Service Curve Number) untuk memperkirakan kedalaman limpasan permukaan.

\section{Debit Banjir Rancangan}

Perencanaan banjir dapat dilakukan dengan 2 cara, yaitu dengan analisis frekuensi data banjir maksimum tercatat, atau perancangan dari analisis data hujan maksimum, kemudian ditransformasikan ke banjir rancangan dengan model hidrograf satuan sintetis Dalam penelitian ini digunakan hidrograf satuan sintetis (HSS) Nakayasu.

\section{Analisis Angkutan Sedimen}

Persamaan yang digunakan untuk memperkirakan angkutan sedimen dalam penelitian ini yaitu antara lain:

\section{Metode Rottner}

Rottner mengembangkan suatu persamaan untuk menyatakan debit pada angkutan sedimen termasuk dalam parameter aliran berdasarkan analisis regresi untuk mengetahui pengaruh parameter kekasaran relatif. Bentuk persamaan Rottner dapat dilihat pada Persamaan (1) 
$\frac{Q_{s}}{\rho_{s} \sqrt{\left(\rho_{s}-\rho_{w}\right) / \rho_{w} \sqrt{g h^{3}}}}=\left\{\frac{\left[0,667(d / h)^{2 / 3}+0,14\right] \times}{\sqrt{\left(\rho_{s}-\rho_{w}\right) / \rho_{w} \sqrt{g h^{3}}}}-0,778(d / h)^{2 / 3}\right\}^{3}$

Dengan $Q_{S}$ adalah debit sedimen $(\mathrm{kg} / \mathrm{s} / \mathrm{m})$, $\rho_{S}$ adalah massa jenis sedimen $\left(\mathrm{kg} / \mathrm{m}^{3}\right), \rho_{w}$ adalah massa jenis air, $g$ adalah gravitasi $\left(\mathrm{m} / \mathrm{s}^{2}\right), h$ adalah kedalaman aliran $(\mathrm{m}), V$ adalah kecepatan aliran $(\mathrm{m} / \mathrm{s}), d_{50}$ adalah diameter butiran $(\mathrm{mm})$.

\section{Metode Van Rijn}

Menurut Van Rijn tingkat angkutan sedimen dapat didefinisikan dengan dua parameter pokok tak berdimensi (dimensionless parameters), yaitu parameter butiran $\left(d_{*}\right)$ dan transport stage parameter $(T)$.

\section{a. Parameter butiran parameter)}

$d_{*}=d_{50}\left(\frac{(s-1) g}{v^{2}}\right)^{\frac{1}{3}}$

Dimana $d *$ adalah parameter butiran, $g$ adalah percepatan gravitasi $\left(9,81 \mathrm{~m} / \mathrm{s}^{2}\right), v$ adalah viskositas kinematik yang diperoleh dari Tabel sifat-sifat air (Properties of
(1)Water) yang dikondisikan dengan temperatur atau suhu air.

\section{b. Transport stage parameter}

$$
T=\frac{\left(u_{*}\right)^{2}-\left(u_{* c r}\right)^{2}}{\left(u_{* c r}\right)^{2}}
$$

Dimana $T$ adalah transport stage parameter, $u *$ adalah kecepatan geser dasar (berhubungan dengan butiran partikel, $(\mathrm{m} / \mathrm{s})$ yang dapat dihitung menggunakan Persamaan (5), C' adalah koefisien Chezy,

$u_{*}=\left(\frac{g^{\frac{1}{2}}}{C^{\prime}}\right) \times V$

Nilai kecepatan geser dasar kritis $\left(u *_{c r}\right)$ dapat diketahui dengan menggunakan Persamaan (6)

$$
u_{*_{c r}}=\sqrt{(s-1) g d_{50} \theta_{c r}}
$$

Nilai $\Theta_{c r}$ diperoleh dari persamaan yang ada pada diagram Shield (Gambar 2) dan disesuaikan dengan nilai dari perhitungan parameter butiran

$(d *)$.

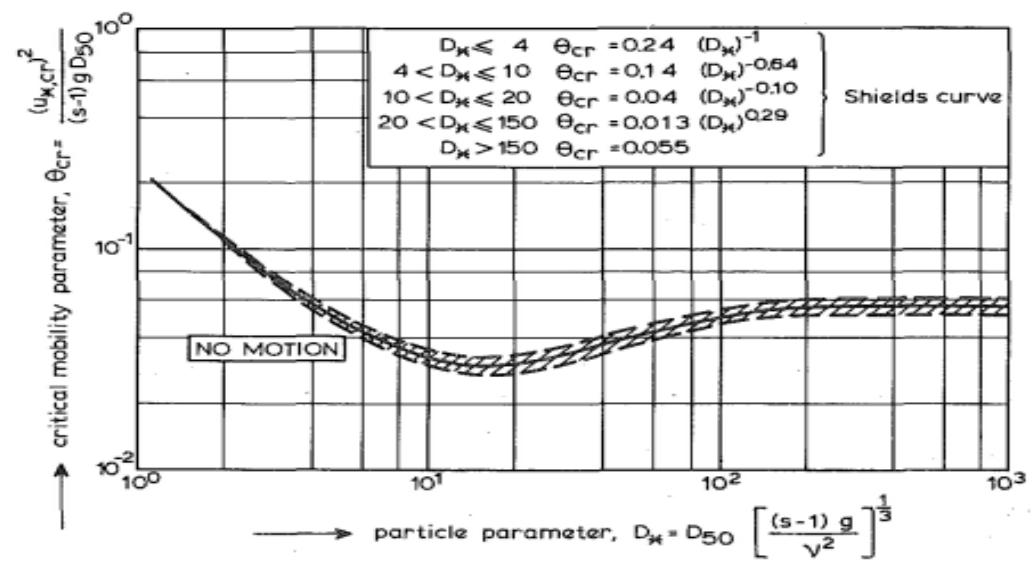

Gambar 2. Diagram Shield

Untuk C' (koefisien chezy) dapat dihitung dengan persamaan (7).

$$
C^{\prime}=18 \log \left(\frac{12 R_{b}}{3 d_{90}}\right)
$$

Dimana $R_{b}$ adalah jari-jari hidrolik, $d_{90}$ adalah ukuran butiran (mm). Maka, jumlah angkutan sedimen dapat dihitung dengan menggunakan Persamaan (8).

$q_{s}=\frac{0,053 T^{2,1}[(s-1) g]^{0,5} d_{50}^{1,5}}{d_{*}^{0,3}}$

Debit angkutan sedimen dasar untuk seluruh lebar dasar saluran dihitung dengan menggunakan Persamaan (9) 


$$
Q_{s}=q_{s} \times B \times \rho_{s}
$$

Dimana $Q_{S}$ adalah angkutan sedimen dasar total $\left(\mathrm{m}^{2} / \mathrm{s}\right)$ dan $b$ adalah lebar sungai $(\mathrm{m})$ $\operatorname{dan} \rho_{s}$ adalah massa jenis sedimen $\left(\mathrm{m}^{3} / \mathrm{s}\right)$

\section{BAHAN DAN METODE}

Lokasi penelitian berada di Sungai Sombe yang merupakan salah satu anak Sungai Palu. Sungai Sombe memiliki luas DAS yaitu $56,67 \mathrm{~km}^{2}$, panjang sungai $10,65 \mathrm{~km}$ dan kemiringan $7,54 \%$. Secara adminstratif terletak di Kabupaten Sigi, Kota Palu, Provinsi Sulawesi Tengah. Penelitian dilakukan dengan mengumpulkan data primer yaitu pengambilan sampel sedimen sebanyak 10 sampel di 10 titik di Sungai Sombe, dengan jarak tiap titik yaitu \pm 150 m. Sampel-sampel tersebut kemudian di uji di Laboratorium dengan pengujian analisa saringan untuk memperoleh nilai gradasi butiran.

Data sekunder berupa data curah hujan (antara 2003-2017) dan data karakteristik DAS (mencakup peta kelerengan, peta geologi dan peta tataguna lahan) yang diperoleh dari BWS Sulawesi III.

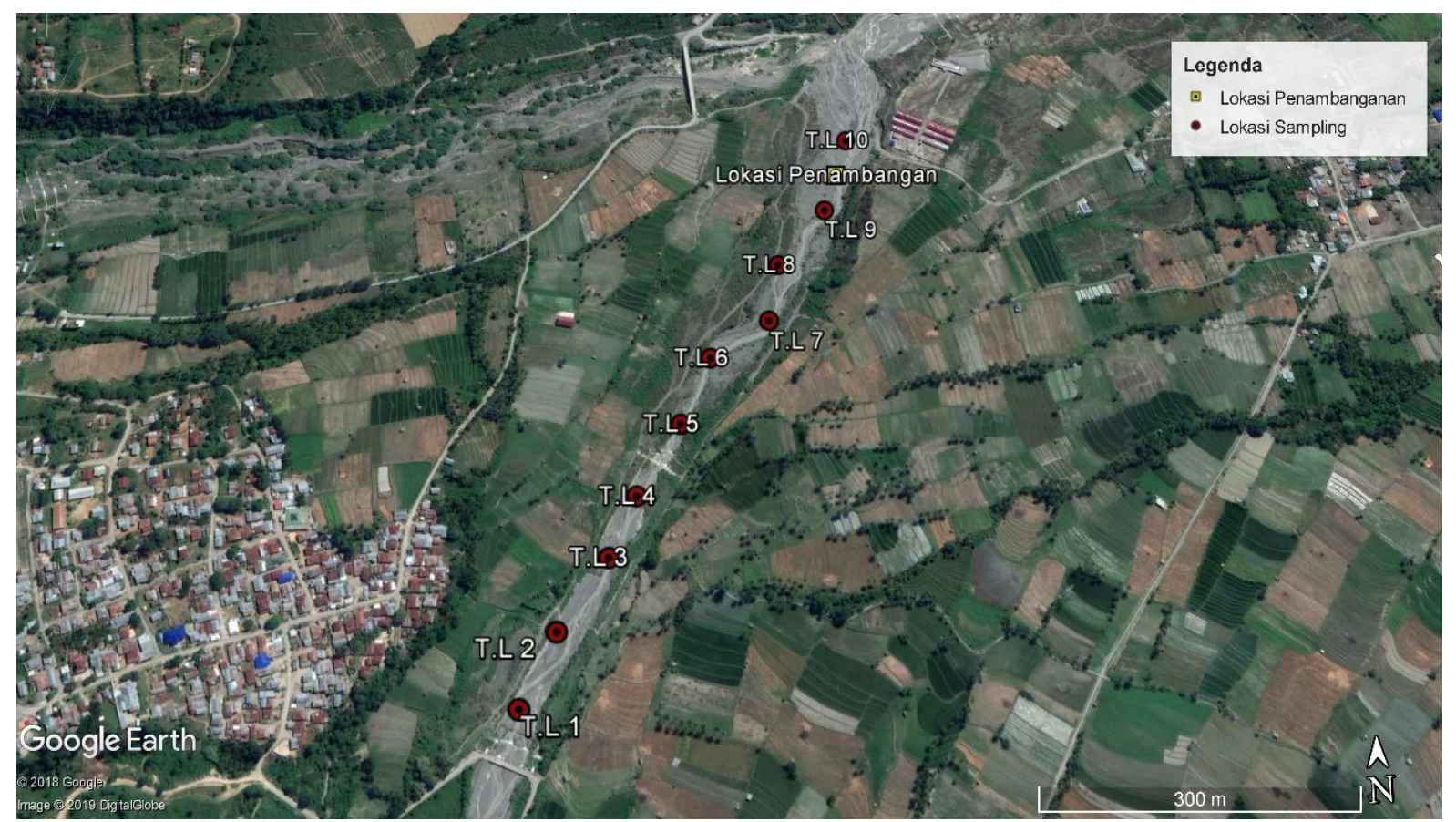

Gambar 3. Titik Lokasi pengambilan sampel dan penambangan pasir di Sungai Sombe

Data curah hujan dianalisis untuk memperoleh debit banjir rancangan. Dari hasil pengumpulan data dan pengujian dilakukan perhitungan angkutan sedimen menggunakan metode Rottner dan Van Rijn. Dari kedua metode tersebut akan dibandingkan dan dipilih metode yang cocok sebagai tolak ukur dalam analisis angkutan sedimen yang ada di Sungi Sombe. Debit banjir rancangan yang digunakan adalah bersumber dari data curah hujan yang dianalisis dengan analisis frekuensi, selanjutnya digunakan metode Hidrograf satuan sintetik (HSS) Nakayasu untuk mentransformasikan hujan menjadi aliran. Sehingga diperoleh nilai debit puncak banjir rancangan adalah $28,50 \mathrm{~m}^{3} / \mathrm{s}$; $45,81 \mathrm{~m}^{3} / \mathrm{s} ; 48,66 \mathrm{~m}^{3} / \mathrm{s} ; 49,01 \mathrm{~m}^{3} / \mathrm{s}$ dengan interval kejadian (periode ulang) yaitu 1 tahunan, 2 tahunan, 5 tahunan dan 10 tahunan. Diasumsikan debit puncak banjir yang diperoleh dari perhitungan merupakan debit banjir yang terjadi sekali dalam peristiwa atau kejadian banjir dengan kala ulang yang ada. sedangkan data sampel yang diperoleh dari pengujian analisa saringan di Laboratorium dapat dilihat pada Tabel 2. 
Tabel 2. Data Sampel Sedimen Hasil pengujian analisa saringan di Laboratorium

\begin{tabular}{c|ccc}
\hline \multirow{2}{*}{ Sampel } & \multicolumn{3}{|c}{ Ukuran Sedimen } \\
& $\mathbf{d}_{\mathbf{3 5}}$ & $\mathbf{d}_{\mathbf{5 0}}$ & $\mathbf{d}_{\mathbf{9 0}}$ \\
$\mathbf{m m}$ & $\mathbf{m m}$ & $\mathbf{m m}$ \\
\hline 1 & 3,6 & 6,5 & 25,5 \\
2 & 3,2 & 8,2 & 33,3 \\
3 & 3,7 & 7 & 23,6 \\
4 & 3,8 & 7,3 & 28 \\
5 & 3,4 & 7,7 & 27 \\
6 & 2,3 & 7,2 & 28,4 \\
7 & 2,1 & 6,6 & 32,5 \\
8 & 2 & 4,6 & 26 \\
9 & 3,4 & 8 & 30 \\
10 & 1,9 & 4,2 & 25 \\
\hline
\end{tabular}

\section{HASIL DAN PEMBAHASAN}

Pada contoh perhitungan dibawah ini digunakan sampel 1 dengan data sebagai berikut:

$$
\begin{aligned}
& \text { Sampel }=1 \\
& \text { Massa jenis air, } \rho_{\mathrm{w}} \quad=1000 \mathrm{~kg} / \mathrm{m}^{3} \\
& =1 \mathrm{gram} / \mathrm{cm}^{3} \\
& \text { Massa jenis sedimen, } \rho_{\mathrm{s}}=2650 \mathrm{~kg} / \mathrm{m}^{3} \\
& \text { Gravitasi, } \mathrm{g} \quad \begin{array}{ll}
= & 2,65 \mathrm{gram} / \mathrm{cr} \\
& =9,81 \mathrm{~m} / \mathrm{s}^{2}
\end{array} \\
& =981 \mathrm{~cm} / \mathrm{s}^{2} \\
& \text { Kemiringan sungai, } \mathrm{S} \quad=0,0754 \\
& \text { Lebar sungai, } \mathrm{b} \quad=36,5 \mathrm{~m} \\
& =3650 \mathrm{~cm} \\
& \text { Suhu air, } \mathrm{T} \quad=28,1^{\circ} \mathrm{C} \\
& =82,58^{0} \mathrm{~F}
\end{aligned}
$$

$\begin{aligned} \mathrm{d}_{35} & =3,6 \mathrm{~mm} \\ & =0,360 \mathrm{~cm} \\ & =0,0036 \mathrm{~m} \\ \mathrm{~d}_{50} & =6,5 \mathrm{~mm} \\ & =0,650 \mathrm{~cm} \\ & =0,0065 \mathrm{~m} \\ \mathrm{~d}_{90} & =22,5 \mathrm{~mm} \\ & =2,550 \mathrm{~cm} \\ \text { Debit } 1 \text { tahunan, } \mathrm{Q}_{\mathrm{b}} & =0,0255 \mathrm{~m} \\ & =28,51 \mathrm{~m}^{3} / \mathrm{s} \\ & =2,85 \times 10^{7} \mathrm{~cm}^{3} / \mathrm{s}\end{aligned}$

Sebelum melakukan perhitungan angkutan sedimen, dilakukan perhitungan luas penampang (A), keliling basah (P), kecepatan rata-rata (V) dan kedalaman aliran (h) menggunakan persamaan manning dengan data yang ada serta data tambahan (diasumsikan) yaitu nilai manning, $\mathrm{n}=0,035$ dan nilai $\mathrm{m}=1$. Persamaan yang digunakan, yaitu :

$$
\begin{aligned}
& A=(b+m h) h ; \\
& P=b+2 h \sqrt{1+m^{2}} ; \\
& V=\frac{1}{n} R^{2 / 3} S^{1 / 2}, \text { maka } ; \\
& Q=A \times V \\
& Q=(b+m h) h \times \frac{1}{n} \times\left(\frac{(b+m h) h}{b+2 h \sqrt{1+m^{2}}}\right)^{2 / 3} \times S^{1 / 2} \\
& 28,51=(36,5+1 \times h) h \times \frac{1}{0,035} \times\left(\frac{(36,5+1 \times h) h}{36,5+2 h \sqrt{1+1^{2}}}\right)^{2 / 3} \times 0,0754^{1 / 2}
\end{aligned}
$$

Dengan menggunakan cara coba-coba dengan $\mathrm{h}=0,25 \mathrm{~m}$, diperoleh :

$28,51=(36,5+1 \times 0,25) \times 0,25 \times \frac{1}{0,035} \times\left(\frac{(36,5+1 \times 0,25) \times 0,25}{36,5+2 \times 0,25 \sqrt{1+1^{2}}}\right)^{2 / 3} \times 0,0754^{1 / 2}$

\section{$28,51=28,51$}

Maka diperoleh nilai $\mathrm{h}=0,25 \mathrm{~m}=25,1 \mathrm{~cm}$, sehingga kecepatan aliran dapat dihitung :

$$
\begin{aligned}
& V=\frac{Q}{A}=\frac{28,51}{(36,5+1 \times 0,25) \times 0,25} \\
& =3,09 \mathrm{~m} / \mathrm{s}=309,44 \mathrm{~cm} / \mathrm{s}
\end{aligned}
$$

Kemudian dilakukan perhitungan angkutan sedimen menggunakan persamaan Rottner (Persamaan 1), sehingga :

$$
\begin{gathered}
\frac{Q_{s}}{\rho_{s} \sqrt{\left(\rho_{s}-\rho_{w}\right) / \rho_{w} \sqrt{g h^{3}}}}=\left\{\begin{array}{l}
{\left[\begin{array}{l}
\left.0,667(d / h)^{2 / 3}+0,14\right] \times \\
\sqrt{\left(\rho_{s}-\rho_{w}\right) / \rho_{w} \sqrt{g h^{3}}}
\end{array}\right.} \\
0,778(d / h)^{2 / 3}
\end{array}\right\}^{3} \\
\frac{Q_{s}}{2,65 \sqrt{(2,65-1) / 1 \sqrt{981 \times 25,1^{3}}}}=\left\{\begin{array}{l}
{\left[0,667(0,650 / 25,1)^{2 / 3}+0,14\right.} \\
\frac{309,44}{\sqrt{(2,65-1) / 1 \sqrt{981 \times 25,1^{3}}}} \\
0,778(0,650 / 25,1)^{2 / 3}
\end{array}\right\}^{3}
\end{gathered}
$$

$$
\begin{aligned}
\mathrm{Q}_{\mathrm{s}} & =177,37 \mathrm{~g} / \mathrm{s} / \mathrm{cm} \\
& =177,37 \mathrm{~g} / \mathrm{s} / \mathrm{cm} \times 3650 \mathrm{~cm} \\
& =6,5 \times 10^{5} \mathrm{~g} / \mathrm{s} \approx 6,5 \times 10^{2} \mathrm{~kg} / \mathrm{s} \\
& =6,5 \times 10^{-1} \mathrm{Ton} / \mathrm{s} \times(24 \times 60 \times 60)
\end{aligned}
$$


$=5,6 \times 10^{4}$ Ton/hari $\mathrm{x}$ (365 hari)

$=2,0 \times 10^{7}$ Ton/tahun

Selanjutnya hasil perhitungan debit angkutan sedimen dengan menggunakan metode Rottner dan Van Rijn dapat dilihat pada Tabel 3 dan Tabel 4 serta Gambar 4 s/d Gambar 7.

Tabel 3. Rekapitulasi perhitungan debit sedimen metode Rottner

\begin{tabular}{|c|c|c|c|c|}
\hline \multirow{2}{*}{ Nomor Sampel } & \multicolumn{4}{|c|}{ Debit Sedimen Dasar (Bed Load) dengan Periode ulang (Ton/Tahun) } \\
\hline & 1 Tahun & 2 Tahun & 5 Tahun & 10 Tahun \\
\hline 1 & $2,0 \times 10^{7}$ & $3,5 \times 10^{7}$ & $3,8 \times 10^{7}$ & $3,8 \times 10^{7}$ \\
\hline 2 & $2,1 \times 10^{7}$ & $3,7 \times 10^{7}$ & $3,9 \times 10^{7}$ & $4,0 \times 10^{7}$ \\
\hline 3 & $2,1 \times 10^{7}$ & $3,6 \times 10^{7}$ & $3,8 \times 10^{7}$ & $3,9 \times 10^{7}$ \\
\hline 4 & $2,1 \times 10^{7}$ & $3,6 \times 10^{7}$ & $3,9 \times 10^{7}$ & $3,9 \times 10^{7}$ \\
\hline 5 & $2,1 \times 10^{7}$ & $3,6 \times 10^{7}$ & $3,9 \times 10^{7}$ & $3,9 \times 10^{7}$ \\
\hline 6 & $2,1 \times 10^{7}$ & $3,6 \times 10^{7}$ & $3,8 \times 10^{7}$ & $3,9 \times 10^{7}$ \\
\hline 7 & $2,0 \times 10^{7}$ & $3,5 \times 10^{7}$ & $3,8 \times 10^{7}$ & $3,8 \times 10^{7}$ \\
\hline 8 & $1,9 \times 10^{7}$ & $3,3 \times 10^{7}$ & $3,6 \times 10^{7}$ & $3,6 \times 10^{7}$ \\
\hline 9 & $2,1 \times 10^{7}$ & $3,7 \times 10^{7}$ & $3,9 \times 10^{7}$ & $4,0 \times 10^{7}$ \\
\hline 10 & $1,9 \times 10^{7}$ & $3,3 \times 10^{7}$ & $3,5 \times 10^{7}$ & $3,6 \times 10^{7}$ \\
\hline Rata - Rata & $2,1 \times 10^{7}$ & $3,5 \times 10^{7}$ & $3,8 \times 10^{7}$ & $3,8 \times 10^{7}$ \\
\hline
\end{tabular}

Tabel 4. Rekapitulasi perhitungan debit sedimen metode Van Rijn

\begin{tabular}{|c|c|c|c|c|}
\hline \multirow{2}{*}{ Nomor Sampel } & \multicolumn{4}{|c|}{ Debit Sedimen Dasar (Bed Load) dengan Periode ulang (Ton/Tahun) } \\
\hline & 1 Tahun & 2 Tahun & 5 Tahun & 10 Tahun \\
\hline 1 & $3,4 \times 10^{7}$ & $5,6 \times 10^{7}$ & $6,0 \times 10^{7}$ & $6,1 \times 10^{7}$ \\
\hline 2 & $3,8 \times 10^{7}$ & $6,1 \times 10^{7}$ & $6,5 \times 10^{7}$ & $6,5 \times 10^{7}$ \\
\hline 3 & $2,9 \times 10^{7}$ & $4,8 \times 10^{7}$ & $5,1 \times 10^{7}$ & $5,2 \times 10^{7}$ \\
\hline 4 & $3,4 \times 10^{7}$ & $5,6 \times 10^{7}$ & $6,0 \times 10^{7}$ & $6,0 \times 10^{7}$ \\
\hline 5 & $3,1 \times 10^{7}$ & $5,1 \times 10^{7}$ & $5,4 \times 10^{7}$ & $5,5 \times 10^{7}$ \\
\hline 6 & $3,5 \times 10^{7}$ & $5,8 \times 10^{7}$ & $6,1 \times 10^{7}$ & $6,2 \times 10^{7}$ \\
\hline 7 & $4,6 \times 10^{7}$ & $7,3 \times 10^{7}$ & $7,8 \times 10^{7}$ & $7,9 \times 10^{7}$ \\
\hline 8 & $5,4 \times 10^{7}$ & $8,8 \times 10^{7}$ & $9,4 \times 10^{7}$ & $9,5 \times 10^{7}$ \\
\hline 9 & $3,4 \times 10^{7}$ & $5,5 \times 10^{7}$ & $5,9 \times 10^{7}$ & $5,9 \times 10^{7}$ \\
\hline 10 & $6,0 \times 10^{7}$ & $9,8 \times 10^{7}$ & $1,0 \times 10^{7}$ & $1,0 \times 10^{7}$ \\
\hline Rata - Rata & $4,0 \times 10^{7}$ & $6,4 \times 10^{7}$ & $6,9 \times 10^{7}$ & $6,9 \times 10^{7}$ \\
\hline
\end{tabular}




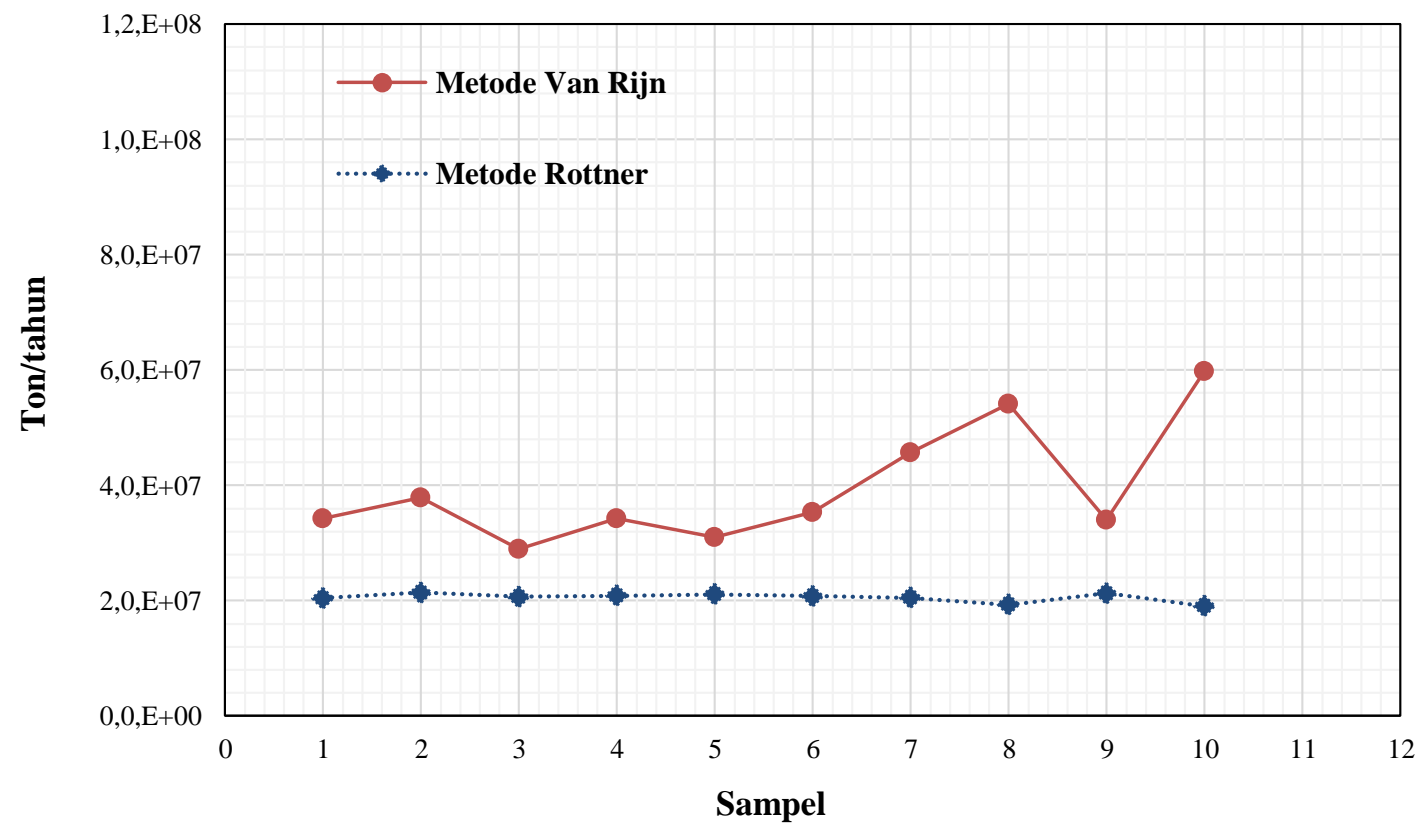

Gambar 4. Hasil analisis debit sedimen dasar (bed load) pada periode ulang 1 Tahunan

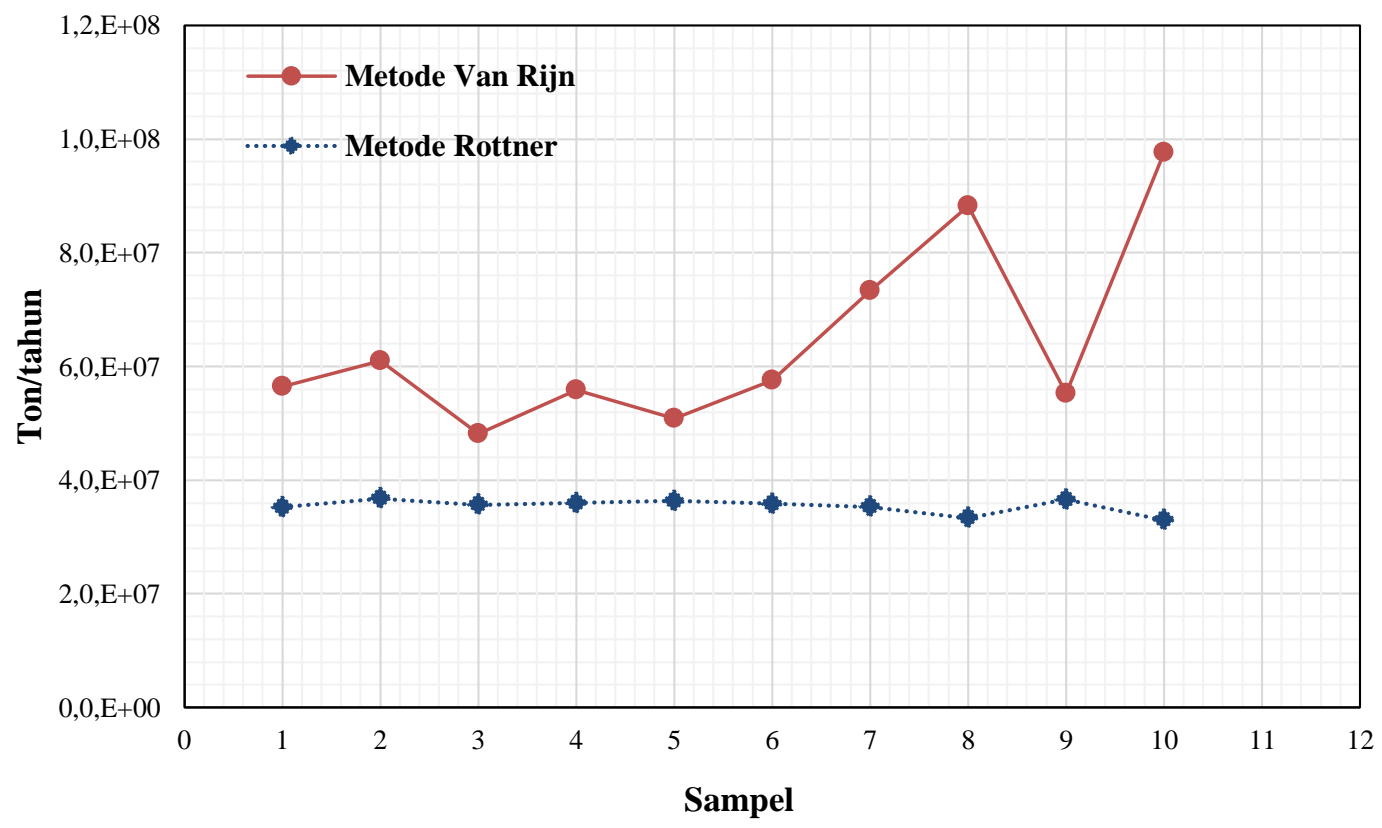

Gambar 5. Hasil analisis debit sedimen dasar (bed load) pada periode ulang 2 Tahunan 


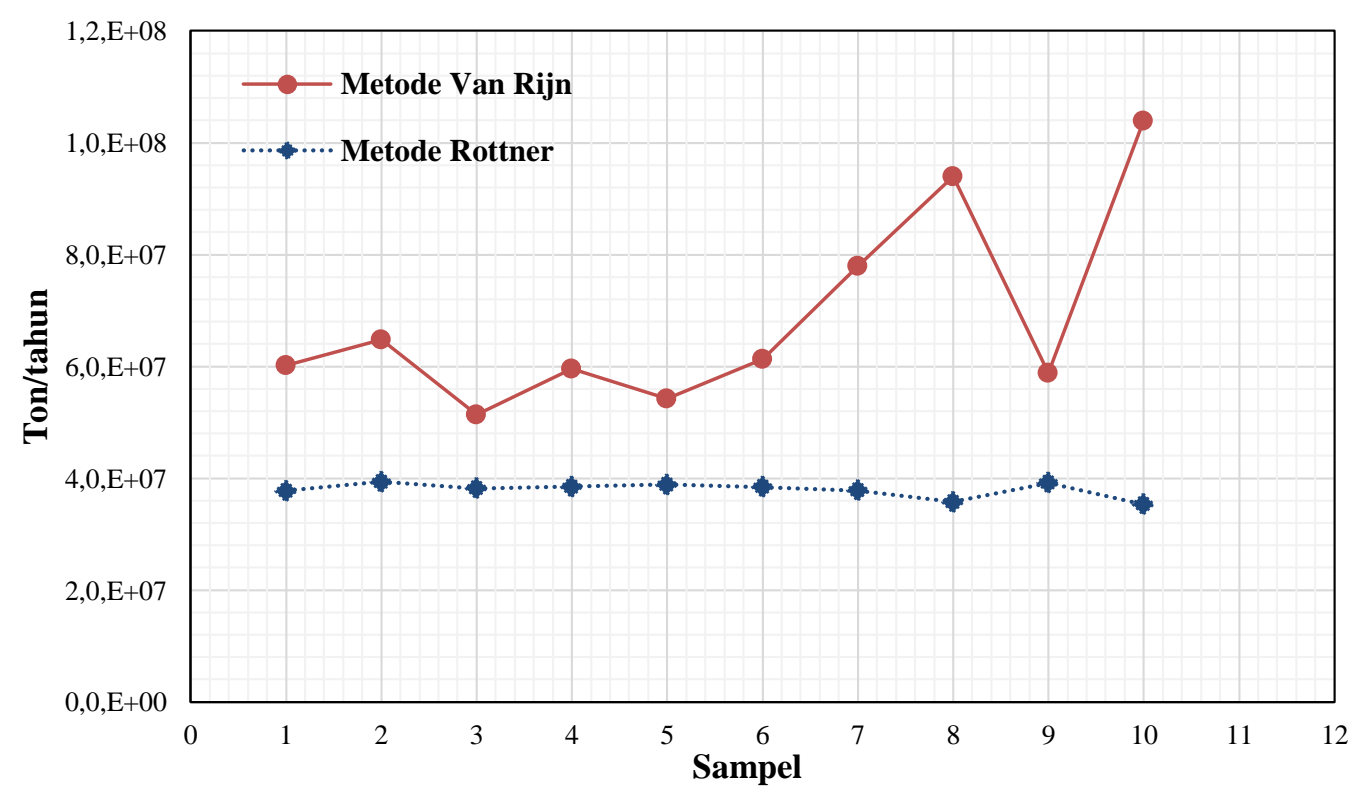

Gambar 6. Hasil analisis debit sedimen dasar (bed load) pada periode ulang 5 Tahunan

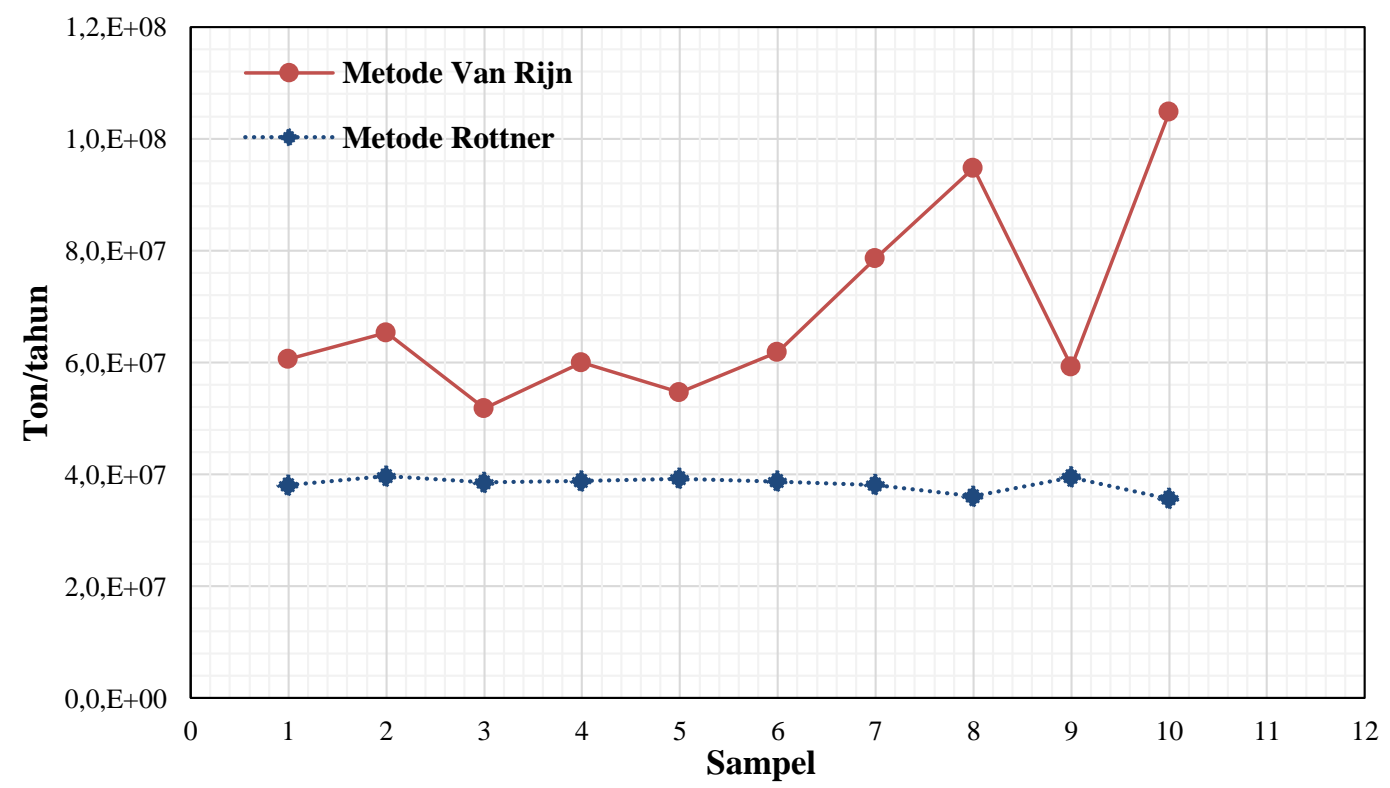

Gambar 7. Hasil analisis debit sedimen dasar (bed load) pada periode ulang 10 Tahunan

Hasil perhitungan dan analisis debit sedimen menggunakan metode yang ada yaitu metode Rottner dan Van Rijn, menunjukan nilai yang berbeda-beda. Perbedaan tersebut dikarenakan karakteristik serta parameter - parameter yang dimiliki kedua metode, selain itu nilai gradasi butiran dari tiap sampel yang berbeda juga menjadi faktor.
Menurut Van Rijn (1984), persamaan dalam menghitung angkutan sedimen dapat sesuai atau disyaratkan untuk diameter butiran yang memiliki nilai range antara $200-2000 \mu \mathrm{m}(0,2-2 \mathrm{~mm})$ sedangkan hasil diameter butiran sampel (untuk metode Van Rijn, diameter butiran yang digunakan adalah $\mathrm{d}_{50}$ dan $\mathrm{d}_{90}$ ) yang diperoleh dari hasil pengukuran melebihi 2 $\mathrm{mm}$. 
Sedangkan Rottner dalam persamaannya menggunakan atau merujuk dari data pengukuran yang dilakukan Gilbert, C.H.MacDougall, S.D.Chyn, Jorissen, U.S.W.E.S., T.Y Liu, C.H.Yen, M.P.O'Brien, H.C Casey dan Pang-Yuang Ho. Dimana pada pengukuran tersebut digunakan diameter butiran yang memiliki nilai range $0,2-15 \mathrm{~mm}$ yang artinya diameter butiran yang diperoleh dari hasil pengukuran sesuai atau termasuk dalam range yang ada.

Atas pertimbangan nilai diameter butiran yang tidak sesuai dan nilai perhitungan yang diperoleh dari metode Van Rijn, maka metode tersebut tidak sesuai untuk digunakan sedangkan untuk metode Rottner sendiri dari nilai diameter butiran dan hasil perhitungan sudah sesuai untuk menggambarkan kondisi dilapangan. Sehingga metode Rottner dipilih sebagai tolak ukur dalam analisis angkutan sedimen di Sungai Sombe.

Analisis terkait aktivitas penambangan dilakukan untuk mengetahui pengaruhnya terhadap perubahan dasar sungai di Sungai Sombe. Pengamatan aktivitas penambangan dilakukan selama 7 hari dengan durasi pengamatan selama 2 jam. Dimana lokasi penambangan tersebut berada diantara titik 9 dan titik 10 dari pengambilan sampel (T.L - T.L 10 ) sehingga diperoleh data sebagai berikut, terlihat pada Tabel 5 .

Tabel 5. Data Penambangan Pasir di Sungai Sombe

\begin{tabular}{|c|c|c|c|c|c|}
\hline \multirow[t]{2}{*}{ Hari } & \multirow[t]{2}{*}{ Jam } & \multirow[t]{2}{*}{$\begin{array}{c}\text { Jumlah } \\
\text { Truk }\end{array}$} & \multirow[t]{2}{*}{$\begin{array}{l}\text { Total } \\
\text { Penambangan } \\
\text { (Jumlah Truk x } \\
\text { Jam Kerja) }\end{array}$} & \multicolumn{2}{|c|}{$\begin{array}{c}\text { Volume penambangan } \\
\text { (Total Penambangan x Kapasitas } \\
\text { Truk) }\end{array}$} \\
\hline & & & & $\mathrm{m}^{3} /$ hari & Ton/tahun \\
\hline 1 & $08.36-10.03$ & 3 & 21 & 147 & 116,87 \\
\hline 2 & $08.20-10.08$ & 3 & 21 & 147 & 116,87 \\
\hline 3 & $08.12-10.05$ & 10 & 70 & 490 & 389,55 \\
\hline 4 & $08.20-10.08$ & 9 & 63 & 441 & 350,60 \\
\hline 5 & $08.02-10.04$ & 3 & 21 & 147 & 116,87 \\
\hline 6 & $08.01-09.58$ & 9 & 63 & 441 & 350,60 \\
\hline 7 & $08.11-10.09$ & 2 & 14 & 98 & 77,91 \\
\hline \multicolumn{4}{|c|}{ Total } & 1911 & 1519,25 \\
\hline \multicolumn{6}{|c|}{$\begin{array}{l}\text { Kapasitas } 1 \text { truk }=7 \mathrm{~m}^{3} \\
\text { Jam kerja penambang rata } \text { - rata berkisar antara } 7 \text { jam }(08.00-15.00) \text { dengan waktu kerja } \\
\text { selama } 25 \text { hari dalam sebulan }(300 \text { hari kerja) } \\
\text { Pengamatan dilakukan selama } 2 \text { jam (artinya } 5 \text { jam sisanya diasumsikan jumlah truk yang } \\
\text { menambang sama dengan pada saat diamati) }\end{array}$} \\
\hline
\end{tabular}

Dari Tabel 5 dapat diketahui bahwa volume aktivitas penambangan pasir yang ada di Sungai Sombe adalah sebesar 1911 $\mathrm{m}^{3} /$ hari. Dengan perkiraan waktu kerja selama 25 hari dalam sebulan (300 hari kerja dalam setahun), maka diperoleh volume penambangan per tahun adalah sebesar 1519,25 Ton/tahun.

Adapun hasil perhitungan volume penambangan dapat dijabarkan seperti berikut ini :
Volume Penambangan $=$ Total Penambangan $x$ Kapasitas Truk

$=21 \times 7 \mathrm{~m}^{3}$

$=147 \mathrm{~m}^{3} /$ hari

$=147 \mathrm{~m}^{3} /$ hari $\mathrm{x} 300$ hari $\mathrm{x} \frac{\rho_{s}}{1000}$

$=147 \mathrm{~m}^{3} /$ hari $\times 300$ hari $\times \frac{2,65}{1000}$

$=116,87 \mathrm{Ton} / \mathrm{tahun}$

Seperti dipaparkan pada bab sebelumnya , bahwa sungai dapat dikatakan dalam keadaan seimbang apabila kapasitas 
sedimen yang masuk ( $Q_{\text {in }}$ ) pada suatu penampang memanjang sungai sama dengan kapasitas sedimen yang keluar (Q $Q_{\text {out }}$ ) dalam satuan waktu tertentu. Apabila kapasitas sedimen yang masuk kurang dari kapasitas sedimen yang keluar Tabel 6. Imbangan Sedimen di Sungai Sombe maka terjadi penggerusan atau erosi, sebaliknya ketika kapasitas sedimen yang masuk lebih dari kapasitas sedimen yang keluar maka terjadi pengendapan atau deposisi. sehingga diperoleh hasil seperti pada Tabel 6 dan Gambar 8.

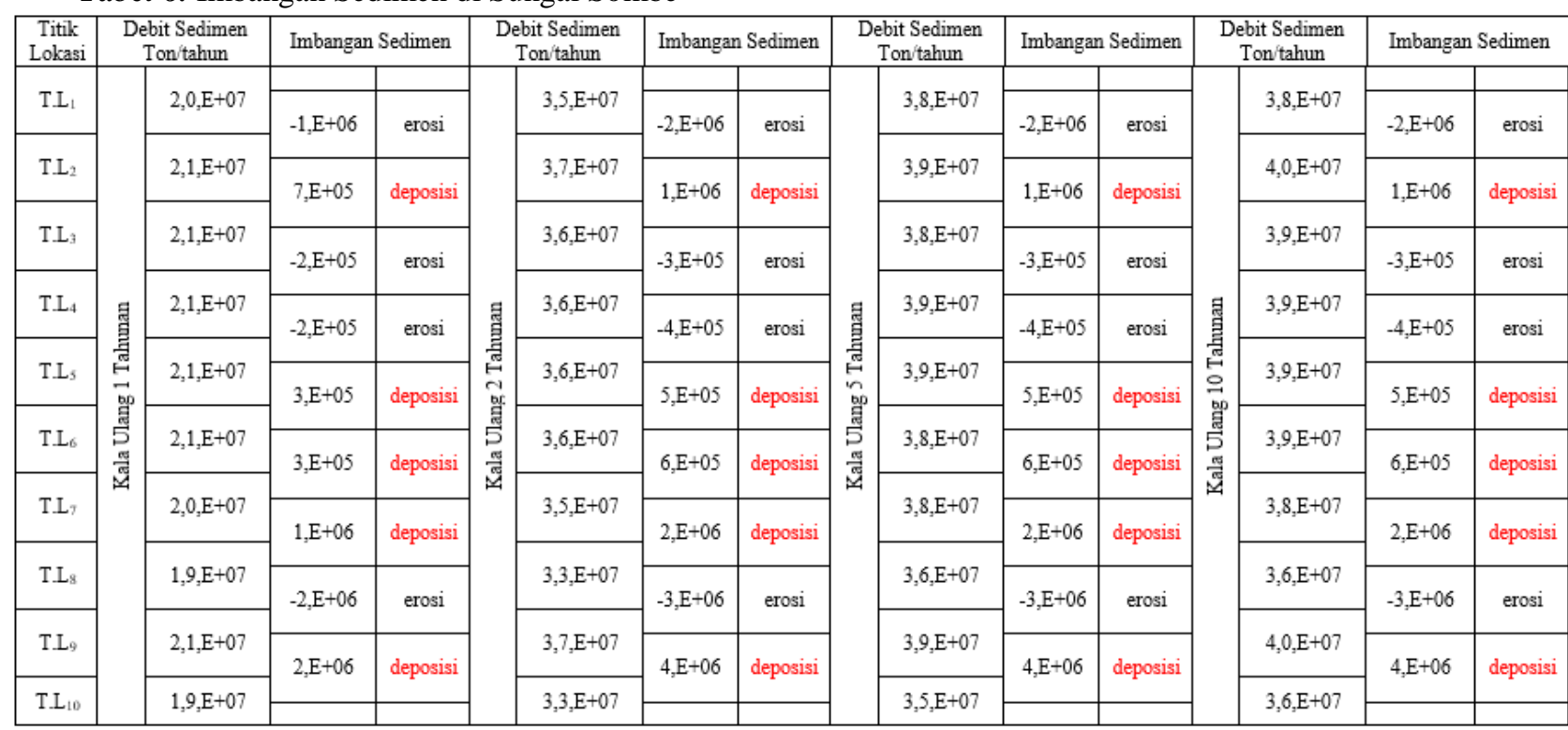

penambangan. Adapun beberapa opsi lain

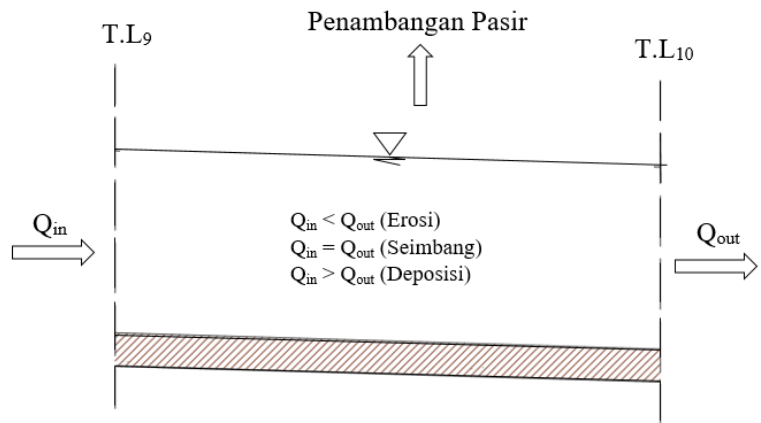

Gambar 8. Skema Angkutan Sedimen dan aktivitas penambangan pasir yang ada pada ruas T.L $\mathrm{L}_{9}-\mathrm{T} . \mathrm{L}_{10}$ di Sungai Sombe.

Dari Tabel 6 dan Gambar 8 diketahui bahwa, debit sedimen yang terdapat aktivitas penambangan didalamnya, memiliki nilai yaitu T.L T $_{9}=2,1 \times 10^{7}$ dan T. $\mathrm{L}_{10}=1,9 \times 10^{7}$, maka :

$=\mathrm{T} . \mathrm{L}_{9}-\mathrm{T} . \mathrm{L}_{10}$

$=2,1 \times 10^{7}-1,9 \times 10^{7}$

$=2,0 \times 10^{6}$

Aliran yang masuk $\left(\mathrm{Q}_{\text {in }}\right)$ pada ruas T.L 9 memiliki nilai lebih besar dibandingkan aliran yang keluar T.L 10 (Q $\mathrm{Qut}_{\text {), artinya }}$ pada lokasi tersebut terjadi pengendapan atau deposisi. Oleh karena itu, pada lokasi tersebut masih dapat untuk dilakukan atau pilihan lokasi yang bisa dipilih selain ruas T.L - T.L 10 sebagai lokasi penambangan yaitu pada ruas T. $\mathrm{L}_{2}-\mathrm{T} . \mathrm{L}_{3}$; ruas $T . \mathrm{L}_{5}-\mathrm{T} . \mathrm{L}_{6}$; ruas T.L $\mathrm{L}_{6}-\mathrm{T} . \mathrm{L}_{7}$ dan ruas T. $\mathrm{L}_{7}-\mathrm{T} . \mathrm{L}_{8}$.

\section{KESIMPULAN}

1. Pada perhitugan dan analisis diperoleh besaran debit sedimen dengan interval kejadian (Periode ulang) yaitu 1 tahunan, 2 tahunan, 5 tahunan, dan 10 tahunan yaitu Metode Rottner sebesar $2,1 \times 10^{7}-3,8 \times 10^{7}$ Ton/tahun, metode Van Rijn sebesar $4,0 \times 10^{7}-$ $6,9 \times 10^{7}$ Ton/tahun. Berdasarkan perbandingan dari kedua metode yang digunakan, diperoleh bahwa metode Rottner dipilih sebagai tolak ukur dalam analisis angkutan sedimen di Sungai Sombe.

2. Adanya perbedaan hasil debit sedimen yang diperoleh dari kedua metode, dipengaruhi oleh nilai gradasi atau diameter butiran dari tiap sampel yang berbeda, serta karakteristik dari 
metode yang digunakan juga menentukan hasil tersebut.

3. Hasil pengamatan yang dilakukan selama 7 hari dilapangan diperoleh volume penambangan pasir di Sungai Sombe adalah sebesar $1911 \mathrm{~m}^{3} /$ hari. Dengan perkiraan waktu kerja selama 25 hari dalam sebulan (300 hari kerja dalam setahun), maka diperoleh volume penambangan per tahun adalah sebesar 1519,25 Ton/tahun.

4. Berdasarkan analisis diketahui bahwa aliran yang masuk $\left(Q_{\text {in }}\right)$ pada lokasi penambangan pasir yakni pada ruas T.L - T. $_{10}$ memiliki nilai lebih besar dibandingkan dengan debit yang keluar $\left(\mathrm{Q}_{\text {out }}\right)$, yang artinya pada lokasi tersebut terjadi pengendapan atau deposisi. Oleh karena itu, pada lokasi tersebut tidak disarankan untuk dilakukan penambangan. Adapun pilihan atau opsi lokasi yang bisa dipilih sebagai lokasi penambangan selain ruas T.L $\mathrm{L}_{9}-\mathrm{T} . \mathrm{L}_{10}$ yaitu pada ruas T.L $\mathrm{L}_{2}-\mathrm{T} . \mathrm{L}_{3}$; ruas T.L $\mathrm{L}_{5}-\mathrm{T} . \mathrm{L}_{6}$; ruas T. $\mathrm{L}_{6}-\mathrm{T} . \mathrm{L}_{7}$ dan ruas T. $\mathrm{L}_{7}-\mathrm{T} . \mathrm{L}_{8}$.

\section{DAFTAR PUSTAKA}

Asdak, Chay., 2010. Hidrologi dan Pengelolaan Daerah Aliran Sungai. Gadjah Mada University Press. Yogyakarta

Chow, V.T.,Maidment, D.R., and Mays, L.W., 1988. Applied Hydrology. McGraw-Hill International Edition, New York.

Fauziyah, Risky., 2018. Study of Sediment Transport At Pabelan River, Magelang Regency, Central Java. Tesis. Yogyakarta: Departemen Teknik Sipil dan Lingkungan, Fakultas Teknik, Universitas Gadjah Mada.

Ikhwan, Rifyanul., Siddhi Saputro., dan Hariadi, 2015. Studi Sebaran Sedimen Dasar di Sekitar Muara Sungai Pekalongan, Kota Pekalongan. Jurnal Oseanografi, Vol.4, No.3. Hal. 617-624, Semarang.
Mulyanto H R., 2007. Sungai Fungsi \& Sifat - sifatnya. Yogyakarta : Graha Ilmu

Pratama, Muhammad Iqbal., 2019. Analisis Angkutan Sedimen pada Sungai Sombe, Palu, Sulawesi Tengah. Tesis. Yogyakarta : Departemen Teknik Sipil dan Lingkungan, Fakultas Teknik, Universitas Gadjah Mada.

Pratama, Muhammad Iqbal.,Djoko Legono.,dan Adam Pamudji Raharjo 2019. Analisis Angkutan Sedimen pada Sungai Sombe, Palu, Sulawesi Tengah. Civil Engineering and Enviromental Symposium. 1 September: V-1

Rafsanjani, H., 2017. Bed Load Analysis of Sesayap River, Malinau District, North Kalimantan Province. Journal of The Civil Engineering Forum, Vol.3 No.3

Rijn, L. C. Van., 1981. Computation of Bed-Load Concentration and BedLoad Transport. Delft Hydraulics Laboratory, Research Report 487I, Delft, The Netherlands

Rottner, J., 1959. A Formula for Bed-Load Transportation. LaHouille Blanche, Vol.14 No.3. pp. 285-307

Saud, Ismail., 2008, Prediksi Sedimentasi Kali Mas Surabaya, Surabaya : FTSP-ITS

Soemarto, CD., 1995. Hidrologi Teknik, Edisi II, Erlangga, Jakarta.

Sri Harto Br., 2009, Hidrologi, TeoriMasalah-Penyelesaian, Nafiri Offset, Yogyakarta

Sudira, I Wayan., Tiny Mananoma., H.Manalip. 2013. Analisis Angkutan Sedimen Pada Sungai Mansahan. Publikasi. Jurnal Ilmiah Media Engineering, Vol.3, No.1, Hal. 54-57.

Sumarauw, Jeffry., 2016. Pola Distribusi Hujan Jam - Jaman Daerah Minahasa Selatan dan Tenggara. Jurnal Sipil Statik. Vol.4 No.11 
Triatmodjo, B., 2009, Hidrologi Terapan, Cetakan kedua, Beta Offset, Yogyakarta

U.S. Interagency Committe., 1957. Measurement and Analysis of
Sediment Loads in Stream.

Minneapolis, Minnesota

Yuliana, Silvya., 2008. Kajian Ulang

Hidrologi. Buku Ajar Fakultas

Teknik Universitas Indonesia, Jakarta. 